\title{
The Middle Path and Pure Experience: A Re-Evaluation of the "Beginning" of Modern Japanese Philosophy
}

\author{
Richard Stone ${ }^{1}$ \\ Received: 14 October 2020 / Revised: 3 February 2021 / Accepted: 2 March 2021 / \\ Published online: 12 May 2021 \\ (C) The Author(s), under exclusive licence to Springer Nature Switzerland AG 2021
}

\begin{abstract}
Nishida Kitarō's (1870-1945) theory of pure experience outlined in An Inquiry into the Good is often uncritically accepted as the beginning of philosophy in modern Japan. While there may be good reason to accept this narrative, it is crucial that we do not do so uncritically. To the contrary, recognizing that Nishida was one philosopher among many and that his work was partially shaped by preceding philosophers in the Meiji era (18681912) can help us gain both a deeper understanding of both Nishida's own thought as well as the developmental process of philosophy in modern Japan. Thus, in this contribution I would like to take one small step towards reconsidering this commonplace narrative by looking at how the thought of one central philosopher of the Meiji era, Inoue Enryō (1858-1919), helped set the stage for Nishida's early philosophy.
\end{abstract}

Keywords Nishida Kitarō $\cdot$ Inoue Enryō $\cdot$ Pure experience $\cdot$ Middle path $\cdot$ Meiji period

\section{Introduction}

For the past century, Nishida Kitarō's (1870-1945) theory of pure experience outlined in An Inquiry into the Good has been largely accepted as the start of independent and original thought in modern Japan. ${ }^{1}$ Indeed, pre-Nishidan philosophical efforts in modern Japan are

\footnotetext{
${ }^{1}$ There are too many works that make this claim in some regard for me to even come close to listing all relevant examples. However, the most common narrative seems to go thus and so: "In the Meiji period (18681912), when Japan reopened itself to the world after more than two centuries of national isolation, a generation of scholars devoted themselves to importing Western academic fields of inquiry, including 'philosophy.' After many years of studying Western philosophy and Eastern classics, alongside a dedicated practice of Zen Buddhism, Nishida was the first major modern Japanese thinker to successfully go beyond learning from the West to construct his own original system of thought. This he began to do in his maiden work, An Inquiry into the Good [...]." (Davis 2019)
}

Richard Stone

rstone328@gmail.com

1 Graduate School of Humanities and Human Sciences, Hokkaido University, North 10 West 7,

North Ward, Sapporo, Hokkaido 001-0020, Japan 
often claimed to have stopped at strict interpretations of Western scholars or simplistic efforts to synthesize traditional Japanese thought and Western philosophy. In contrast with this, it is said that in An Inquiry into the Good, Nishida attempted to provide the most concrete expression of reality possible outgoing from "pure" experience, i.e., "direct" experience that stands before any distinction between subject and object, thus giving him a an utterly unique viewpoint. Yet, in spite of the old tendency to treat Nishida's philosophy as if it was the result of either his sheer individual genius or his experience of practicing $z a z e n,{ }^{2}$ we would do well to emphasize the fact that he was actually only one philosopher in his era among many, and that his writing was (at least partially) shaped by trends within the Meiji era (1868-1912). Keeping this in mind, in this contribution I would like to take one small step towards relativizing such common narratives by looking at how the thought of one central philosopher of the Meiji era, Inoue Enryō (1858-1919), helped set the stage for Nishida's philosophy of pure experience.

Founder of the first philosophical journal in Japan, member of the Seikyōsha publishing group, expert debunker of superstitions and ghost stories, noted Buddhist reformer, and critic of Christianity, Inoue Enryō played a central role in many Japanese intellectual circles in the late 19th and early twentieth century. ${ }^{3}$ However, possibly due to sheer breadth of his thought, it would seem that the content of his philosophy itself has still yet to receive its proper recognition in comparison with how his arguments influenced other fields. Rather, in extreme cases, Inoue has even been accused of "deploying" philosophy with the intent of using it as a tool to legitimize his claims in other practical debates (specifically those concerning Buddhism as a rational or scientific religion). ${ }^{4}$ Additionally, his philosophy has occasionally been treated as a form of "mere" syncretism. In other words, Inoue's work has at times been treated as little more than a theoretically incomplete attempt to synthesize ideas he picked up in Buddhist thought with Western philosophy. ${ }^{5}$ With that said, however, a closer inspection of

\footnotetext{
${ }^{2}$ While we will not investigate the reasoning for his belief, Shimomura Toratarō provides a classic case of this point in his denial of Nishida's connection to other philosophers (like William James, in this case): "The concept of pure experience may have its roots in the philosophy of empiricists like James who were popular in Japan at the time. Of course, Nishida likely gained many insights and refinements from these psychological analyses and conceptual explanations. However, should we not [instead] say that his philosophy was essentially borne from his experience practicing meditation?" (Shimomura 1990, 43-4)

${ }^{3}$ Information concerning Inoue's connection to the Seikyōsha and the national preservation (kokusui hozon) movement can be found in Pyle (1969). Information related to his work on superstitions and ghost stories (more broadly speaking, his yōkaigaku) is available in sources like Josephson (2006). His role in reforming Buddhism is discussed from various perspectives in Snodgrass (2003), Okada (2005), and Kopf (2013), just as examples. Additionally, discussions of his complicated relationship with Christianity can be found in Staggs (1983) and Paramore (2009). Finally, a comprehensive introduction to Inoue's life and work in its historical context is available in Schultzer (2019).

${ }^{4}$ In Particular, Judith Snodgrass argued that Inoue's philosophy served mainly to validate his claim that Buddhism - and not Christianity - was the religion best fitting modern Japan, stating that " [...] by denouncing it [i.e., Christianity] from the supposedly impartial stance of philosopher, Inoue enlisted the support of an audience beyond Buddhists. He did not simply dismiss it as evil but analyzed it as irrational, conceptually untenable, prescientific, deleterious to Japan. By taking the title "philosopher" Inoue was able to promote Buddhism and undermine Christian influence from a pedestal of rationality and objectivity." $(2003,141)$

${ }^{5}$ To be more specific, pre-Nishida Buddhist philosophy in general has tended to receive such treatment. For example, Kosaka Kunitsugu (1995) specifically cites Inoue Enryō and Kiyozawa Manshi as being such cases of mere "syncretism" between Western philosophy and Buddhist thought. Kosaka Masaaki (1959/1999, 2656), refers to the work of Inoue Enryō, Inoue Tetsujirō, and Miyake Setsurei as being more of a "metaphor (比 喻)" or “sketch (描写)" of their respective systems than an evidence-based “demonstration (論証)."
} 
Inoue's thought shows that the role he played in the development of philosophy in modern Japan cannot be so easily dismissed. This is true not only in terms of his work in introducing Western philosophers (or, indeed, the concept of philosophy itself) into Japanese society, but also in terms of providing novel philosophical arguments that stimulated later philosophers such as the aforementioned Nishida. ${ }^{6}$ Indeed, in spite of the relative lack of attention his metaphysical thought has received, I believe we can find in Inoue's thought an attempt to provide a concrete expression of reality that resonates with many of Nishida's goals. More specifically, I believe that Inoue's attempt to pursue an account of the "middle path (中道)" between extreme positions such as idealism and materialism offered several insights that played an important role in early modern Japanese philosophy and - more specifically - helped create the field of concepts and central problems that shaped Nishida's philosophy.

Keeping all of this in mind, we shall endeavour to reconsider the development of philosophy in modern Japan by engaging in the following two goals. First, we shall aim to provide a reconstruction of Inoue's position while focusing largely on the argument provided in the first section of An Evening of Philosophical Conversation. Upon establishing the basic argument behind Inoue's notion of the "middle path," we will aim to show both how his efforts link to Nishida's early philosophy of pure experience. More specifically, we will establish that Inoue's struggle against materialism and idealism left Nishida with the crucial challenge of how one can possibly give a positive account of reality in the most concrete way possible without reducing it to abstract or biased positions. Subsequently, in the third section, we will look at pure experience as a methodological principle aimed to tackle this problem left behind by Inoue. Finally, in the conclusion, we will use these findings as a basis to briefly consider what (if anything) the common narrative that Nishida is modern Japan's first original philosopher could possibly mean. As a result of this exercise, I hope to point to a potential shortcoming in our current narratives concerning both the progression of modern Japanese philosophy and the formative process of Nishida's philosophy.

\section{Inoue's Philosophy of the Middle Path - Focusing on An Evening of Philosophical Conversation}

An Evening of Philosophical Conversation was written in three pamphlets released between 1886 and 1889. In addition to being a favorite book of the young Nishida, this work has been taken by some historians as the first full-fledged instantiation of the broader tendency towards theories that have been referred to under the umbrella of

\footnotetext{
${ }^{6}$ As Nishida himself states, “[...] in the beginning I wasn't thinking about studying philosophy. Originally, I was thinking about going into science. However, at that time [when I was in high school] I read a thin pamphlet called An Evening of Philosophical Conversation written by a man named Inoue Enryō and found it to be very interesting, and this stimulated me to start moving toward [the study of] philosophy." (Nishida 2003, 80) Accounts of the young Nishida's interest in An Evening of Philosophical Conversation can be found in varying sources. Kosaka $(1971,20)$ and Takeuchi (1970, 54-7) mention An Evening of Philosophical Conversation as the starting point of Nishida's philosophical career. In terms of clear comparisons between the two Wargo (2005) and Shirai (2012) both provide important insights on the similarities and differences between An Evening of Philosophical Conversation and Nishida's early philosophy.
} 
"phenomena-soku-reality." Perhaps more importantly, however, the work presents a crucial counter-example to general assumptions that pre-Nishidian Meiji philosophical efforts were universally translational or limited to interpretations of Western texts. The central premise of the work is that it presents a dialogue between discussants representing logical extremes, only to fall into unsolvable aporias. The various parties face off in three different sections, respectively covering the topics of ontology, god, and truth. In the first section, which is both the basis for Inoue's work in the remainder of the dialogues and likely the foundation of his philosophy, a "materialist (Enyū)" and an "idealist (Ryōchū)" find themselves determined to show that reality is entirely reducible to physical material and conscious phenomena respectively. ${ }^{8}$ Enyū and Ryōchū take turns rigorously pushing forward their own agenda, only to ultimately end with unanswerable questions (and thus fail to justify their positions). Considering not only the fact that the first section of An Evening of Philosophical Conversation is the basis of Inoue's ontology, but also the fact that it offers us the key to understanding the problem he left for later philosophers in Japan, I would like to start with a brief introduction to this dialogue.

The dialogue starts with the idealist Ryōchū remarking that no matter how vast the universe may be, it can only be as vast as we grasp it to be in our minds. That is to say, everything we perceive, no matter what it is, is only available to us in the human mind. To speak of anything outside of the human mind that we cannot have a mental experience of would be far too speculative. Even when his materialist opponent, Enyū, fires back that it is equally speculative to assume that there is nothing beyond the mind, Ryōchū is prepared to answer. That is, for Ryōchū, the very act of distinguishing between any object (including whether something is 'in' or 'outside' of the mind) is a mental act. Ryōchü's theory here goes up in scale, revealing itself to be based on a singular mind, which then articulates itself through discriminatory mental acts. However, just as soon as Ryōchū expounds upon this theory, Enyū points out that this notion makes a mockery of the fact that they are two distinct persons who are having a conversation precisely because they do not share the same mind and that, at any rate, Ryōchū has failed to account for how this discriminatory process of individuation occurs. Ryōchū's defeat is followed by Enyū's own attempt to describe his materialist position. As far as Enyū is concerned, the world is made up of physically discrete and separate individual objects. With regard to how to account for the mind, Enyū chooses to make a sharp distinction between spatially discrete individual material objects and

\footnotetext{
${ }^{7}$ Here I am using “phenomena-soku-reality (現象即実在)" to refer to the broader tendency in Meiji philosophy to provide an ontology that does not presuppose any "thing-in-itself" or mind-independent world behind conscious phenomena. Funayama Shinichi (1959/1965) in particular claimed Inoue's An Evening of Philosophical Conversation to be the first substantial contribution to this movement. While I would largely agree with Funayama here, two points require caution. First, Inoue Enryō himself did not use this term to refer to his own philosophy. The term phenomena-soku-reality properly belongs to his contemporary, Inoue Tetsujirō. As such, we cannot easily assume Inoue Enryō and Inoue Tetsujirō are endorsing the same theory. Second, in line with the spirt of this paper, it is important not to assume that Inoue Enryō appeared out of nowhere. Indeed, Inoue Enryō, as well as all other authors commonly associated with phenomena-soku-reality took classes from Hara Tanzan at Tokyo University, whose reading of the Awakening of Faith in the Mahayana has been understood as a proto-typical version of trends in Meiji philosophy (See Watabe 1998).

${ }^{8}$ Here we should take their respective allegiances with a grain of salt. In particular, the "materialism" in this dialogue is, as Shirai Masato has argued, perhaps something closer to a dualist position than what we typically refer to as materialism. (Shirai 2012, 102)
} 
consciousness. What's more, after Ryōchū presses him on the topic of death and the possibility that spatial differences between individuals are only a temporary state, Enyū is forced to imply the immortality of the soul. Yet, in the end, when Ryōchū further asks him what will happen when the universe itself meets its inevitable end and there is no longer any possibility to account for physically distinct individuals, Enyū is unable to come up with a means to keep his worldview from collapsing in on itself.

It is here, once both idealism and materialism have reached an impasse in trying to describe the true nature of reality that both Enyū and Ryōchū attempt to appeal to the authority of their teacher: Enryō. As one can surmise by looking at the names of all participants, Enryō-sensei serves to unite the fragmentary truths provided by Enyū and Ryōchū. ${ }^{9}$ Upon being provided with a summary of their debate, Enryō-sensei does not side with either of the two students. Rather, he chides the two of them, stating that:

\begin{abstract}
"Ryōchū knows non-discrimination but knows nothing of discrimination. Enyū knows discrimination but knows nothing of non-discrimination. Neither of you have escaped from being biased toward one side or the other. This is the reason that both of you are able to [so easily] doubt the other's explanation. You are both convinced that non-discrimination and discrimination and the entity [body; 体] they make up are entirely different. Ryōchū's so-called non-discriminatory mind is the same thing as Enyū's discriminatory mind, and Enyū's discriminatory mind is the same thing as Ryōchū's non-discriminatory mind. They both make up one part of the same entity. Thus, we have what Buddhist logic calls the soku relation." (IES 1987, 43)
\end{abstract}

In this quote, we find the core premise of Inoue's philosophy. Neither materialism nor idealism are entirely wrong. Materialism - as a world view in which the world is composed of physically distinct individuals - must exist in a relation of immediate interdependence (expressed here as the logic of 'soku') with idealism - as a worldview in which individuals emerge from a non-discriminate whole through mental acts. Indeed, according to Enryō-sensei (and thus Inoue Enryō the author), they both represent one fundamental moment inherent to reality in its most complete state. When we try to reduce reality to either extreme or take one as fundamental to the other, we end in absurdity. This declaration on the part of Enryō-sensei (as well as some more or less helpful metaphorical explanations to help the reader grasp the middle or perfect path) marks the end of the first section of An Evening of Philosophical Conversation.

Now, before moving on, there are two salient points about Inoue's middle path that deserve attention. First, Inoue's middle path is not a static entity that houses both mind and matter as two separate entities. To the contrary, mind and matter cannot be treated as being entirely separate from one another, for they are both part of the same dynamically changing complex. Or rather, as Inoue emphasizes, "Non-discrimination develops itself into discrimination, while discrimination merges into non-

\footnotetext{
$\overline{9}$ This play on words works on two levels. As one can see even in English, Enyū and Ryōchū both make up half of "Enryō", both in terms of writing the name out and in terms of his system of thought). Additionally, we must also remember that the characters for Enryō's very name means "completion". Thus, the teacher Enryōsensei, who has gone past one-sided or overly simplified extremes, has been able to reach a more total or complete view of reality.
} 
discrimination." ${ }^{10}$ For Inoue, non-discrimination (expressed initially by Idealism) and discrimination (represented by materialism) exist in a relation of ebb and flow, feeding into one another. In conjunction with this, we should recognize that Inoue's middle path is not a completely different alternative to materialism or idealism, but instead as the originary activity that stands at the basis of this interplay between them and makes such distinctions possible in the first place.

The second point we must recognize is that, although the arguments the discussants provide are often shrewd, the structure of this pamphlet is likely of even greater interest to us than its content. When reading this text, it is important that we avoid a crucial mistake and do not look at the lectures of Enryō-sensei as an immediate or mystic revelation of the truth of the middle path to his hapless students. To do so would be to ignore the dialectical development in which Enyū and Ryōchū systematically negate each another and gradually become indistinguishable over the course of their own dialogues. It is only once their individual positions have collapsed into one another that Enryō-sensei, as the representative of the middle path, can point out to his students a fact that should have already become clear from their own discussion: any attempt to reduce reality to one particular entity (and thus do away with other positions) was bound to be nothing more than a hollow abstraction. Given this fact, any such attempt to pigeon-hole reality as being precisely this, that, or the other, will necessarily reveal itself to be entirely incomplete when taken to its extreme.

Considering what we have mentioned above, it seems fair to say that Inoue's argument in An Evening of Philosophical Conversation is hardly reducible to the "mere" creatively bankrupt syncretism that less generous interpretations have saddled upon him. Indeed, insofar as I can tell, these dialogues are best looked at as a kind of internal struggle to do philosophy without resorting to the seemingly inevitable fate of extreme or biased positions. ${ }^{11}$ While we do not have time to look at the matter in detail, it is worth noting that the development between discussants presented here matches his unique view on the development of the history philosophy as an oscillation between - and attempt to escape from - extreme or biased positions. ${ }^{12}$ Perhaps more than any historical speculation, though, the performative nature of Inoue's dialogues in An Evening of Philosophical

\footnotetext{
${ }^{10}$ IES 1: 45

${ }^{11}$ This may be visible in Inoue's response to critics claiming that the seemingly all-knowing teacher being named Enryō is a sign of hubris. According to Inoue himself, these dialogues are marked by his attempt to describe this middle path without endorsing any of the old or biased positions of yore. I would thus argue that Inoue's struggle was an internal one, in which he allowed these positions to combat one another until there was nothing left but the middle path. (IES 1: 48-9)

${ }^{12}$ Inoue explains this view on the development of the history of philosophy by using modern Western philosophy as an example in An Introduction to the Vitalization of Buddhism (1887): "What are the theories that comprise modern philosophy? We could say they are materialism, idealism, or logicism (唯理). [...] In the beginning, Locke advocated empiricism. Then Leibniz advocated substantialism (本体論) before Kant came to synthesize these positions. Those like Hume tended to be biased toward materialism while those like Berkeley tended to be biased toward idealism. This led to Reid syncretizing the two positions with his mind-body dualism. While Fichte took the subject and Schelling the object [as primary], Hegel harmonized their positions. The German school thus became biased toward speculation (空理) while the Scottish school was biased toward common-sense. He who synthesized these two positions was Cousin in France. Spencer feared becoming biased toward either the knowable or the unknowable and thus tried to make a divide between them. Modern philosophy has thus been unable to escape from these [biased] theories. Hence, [modern philosophers] all run toward one extreme theory, and while they may desire to find a balance (中正を保持せんと欲して), they have been unable to achieve this goal." (IES 3: 361) A more detailed account about how Inoue understood the history of philosophy is available in Godart (2004).
} 
Conversation can help the reader catch a glimpse of reality that cannot be reduced to any one particular position. In this way, Inoue's work presents (and poses a negative solution to) the question of how it is possible to describe reality without falling victim to bias and abstraction. In the next section, we will briefly review how these questions connect him to Nishida's attempt at a philosophy of pure experience.

\section{From Inoue to Nishida: Similar Ideas and Unanswered Questions}

To begin, although our introduction of Inoue's philosophy has been exceedingly brief, readers of Nishida's philosophy have likely seen enough to identify how some of the core themes in his work overlap with many of the crucial themes in An Inquiry into the Good. ${ }^{13}$ First, Inoue's decision to take the middle path to show that subjective consciousness and objective materiality form "true reality" as two interpenetrating aspects of one encompassing whole resonates clearly with central ideas in Nishida's philosophy. Indeed, similarly to our outline of Inoue's philosophy, even a cursory analysis of pure experience shows that Nishida also claims that oppositions exist as necessary aspects of an overarching unity. ${ }^{14}$ Or, to be more precise, in both systems, the constant dynamism of this unity, i.e., Inoue's middle path or Nishida's pure experience, is taken as the originary source of the various differences in perspectives and contexts that allow us to designate one aspect of this underlying unity as being either the individual's subjective consciousness or objective material. To this extent, to imply that one is "more real" than the other is arbitrary at best, and the source of needless theoretical conflict at worst. As Nishida states, these distinctions are no more than differing perspectives on pure experience. ${ }^{15}$

Rather than focusing solely on particular similarities, however, I believe it is more important to note that Inoue helped point later philosophers like Nishida to an important problem. ${ }^{16}$ That is to say, as the previous section likely made clear, Inoue's philosophy offered a glimpse into what Robert J. J. Wargo - in his analysis of the relation between Inoue Tetsujirō, Inoue Enryō, and Nishida - has referred to as the "problem of standpoints." 17 Indeed, the dialogues in An Evening of Philosophical Conversation serve as an efficacious reminder that all attempts to pigeon-hole reality into one -ism or another, or otherwise to attempt to do away with other perspectives by accounting for a purely materialist/idealist world separated from its counterpart, were bound for failure. Considering this fact, Inoue attempted to show a way toward accounting for both the

\footnotetext{
${ }^{13}$ Shirai (2012) and Wargo (2005) have likely given the most detailed analyses of the similarities between the two. Here, we will only briefly review their specific similarities in order to focus more on the root of their shared philosophical intuition.

14 "In the establishment of reality, then, both a unity at the base of reality and mutual opposition or contradiction are necessary. [...] When these contradictions disappear, reality disappears as well. On a fundamental level, contradiction and unity are simply two views of the same thing. Because there is unity there is contradiction, and because there is contradiction there is unity." (Nishida 1990, 56)

15 "It is usually thought that subject and object are realities that can exist independently of each other and that phenomena of consciousness arise through their activity, which leads to the idea that there are two realities: mind and matter. This is a total mistake. The notions of subject and object derive from two different ways of looking at a single fact, as does the distinction between mind and matter." (Nishida 1990, 49)

16 Those interested in a more exhaustive discussion of how similar Inoue and Nishida are should look at Shirai (2012).

${ }^{17}$ Wargo 2005, 11
} 
underlying (and not directly describable) unity between the various perspectives presented in these debates without absolutizing any of them. Indeed, as we have ascertained in the last section, for Inoue both mind and matter were admitted as valid perspectives that comprise a more comprehensive unity. This attempt to describe reality in the most concrete way possible by capturing the difficult relation between the multiplicity of relative perspectives and the unity between them, then, is a crucial project left by Inoue and likely inherited and developed by Nishida.

With that said, however, there are crucial differences between the two in how they approach this problem. In this sense, it is important that we remain aware of the fact that Inoue did not exactly "solve" the issue at hand. More specifically, as several authors have pointed out, the matter of how one can provide a non-dual account of reality raises important questions that remain unanswered (or, perhaps better, unanswerable by design) in Inoue's dialogue. Consistent with what we have seen in the dialogue in An Evening of Philosophical Conversation, Inoue seemed to prefer a negative approach to accounting for the middle path. In other words, for Inoue, the middle path can only be glimpsed in the negation of extreme positions and metaphorical images to help one grasp a concept of reality that is otherwise ungraspable. Yet, although the arguments designed to show that extreme positions cannot be absolutized or cut-off from other perspectives are enlightening, Inoue's dialectic never provides a clear or systematic account of what the middle path is or how it should be characterized. Or, to be more precise, the skeptical claim that reality can only be approached negatively denies the possibility of doing so. Yet, while Inoue's reasons for avoiding a positive description of the middle path may be clear, this point still opened him to various criticisms going back to the initial publication of the pamphlet. Indeed, Inoue's attempt to explain through Enryō-sensei how mind and matter are at once the same and not the same was decried as an unjustified acceptance of contradictions (as one of his earliest critics, Onishi Hajime put it, Inoue seems to have merely mixed oil and water). ${ }^{18}$ Even as Inoue's career progressed, it would appear as though he never developed a serviceable account of how mind and matter or subject and object go about distinguishing themselves from one another. ${ }^{19}$ In the end, as Wargo correctly states in regard to Inoue's ontological theory, the claim that reality was non-dual was seemingly posed as the solution to all of philosophy's problems. However, as he also points out insofar as there is no substantial attempt to provide a theoretical foundation for this nondual ontology - this assumption is incorrect. ${ }^{20}$

Several authors have used such potential criticism as evidence to state that there is a gap in philosophical rigor between Inoue and Nishida. ${ }^{21}$ More specifically, although

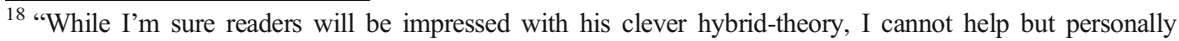
wonder: has not Enryō-sensei [merely] attempted to mix oil and water here?" (Onishi 1887/2014, 27)

${ }^{19}$ Even Nitta Yoshihiro, in his admirable attempt to push Inoue's later philosophy in A Proposal for a New Philosophy to its upper limits, concedes in that Inoue's work was "underdeveloped" and that, insofar as it gave no practical account of how reality differentiated itself as such, it stops at being a "contemplative" philosophy of merely looking at material reality or conscious phenomena from different perspectives. (Nitta 1989, pp. 978)

${ }^{20}$ Wargo 2005, 31; note that this critique is also applied to the other major author associated with the broader notion of phenomena-soku-reality, Inoue Tetsujirō.

${ }^{21}$ Examples of scholars who refer to this possibility: Funayama (1959/1965), Nitta (1989), and Wargo (2005). Maraldo (2017) mentions in passing a difference in critical method between those like Inoue and those like Nishida and Onishi Hajime. Moreover, as we shall mention again later, Itabashi (2004) also makes similar arguments for difference in methodological rigor in his discussion of Nishida and Inoue Tetsujirō.
} 
we have just seen that Inoue's metaphysics has been criticized for not providing a systematic foundation to accept his non-dual ontology, such criticism hardly seems applicable to Nishida's philosophy of pure experience. ${ }^{22}$ To the contrary, one could likely go so far as to say that the matter of how a fundamentally unified reality is capable of constantly changing, developing, and differentiating itself into apparent dualities was the core of Nishida's early thought (and, possibly, the driving force of his career as a philosopher). ${ }^{23}$ While we do not have space here to thoroughly explain the dynamics of Nishida's system, it is likely that his account of the development of the various rifts that open and reunite within the underlying unity of pure experience is capable of providing answers to the points of Inoue's philosophy doubted by his critics in the prior paragraph.

Naturally, we should not look at this distinction as devaluing Inoue's philosophical project in any way. After all, one could hardly say that Inoue failed in An Evening of Philosophical Conversation. To the contrary, insofar as he led his readers to the point at which only the middle path remained, one could look at his endeavour as a success with respect to his philosophical goal. Additionally, in response to his critics, one could argue that his negative approach was the only viable conclusion for his investigation. More importantly though, Inoue pointed to a crucial methodological problem: how could one provide a concrete account of the reality we live in given that any attempt to grasp it in its entirety would be doomed to failure as an externalized abstraction that takes into view only one part of the bigger picture? I believe that this question helped set the stage for Nishida's more systematic endeavor to describe pure experience. Keeping this in mind, in the next section, we will briefly look at how Nishida attempted to positively and systematically describe pure experience - i.e., the sole reality - without falling prey to such abstractions.

\section{Nishida's Early Methodology: Changing the Starting Point of Philosophy}

As readers of An Inquiry into the Good will be aware, pure experience is taken to be the most concrete expression of reality as it is given to us in our most direct or obvious experiences. As Nishida explains from the outset of this work, such "direct" experience reveals that there is no intrinsic distinction between subject and object or mind and

\footnotetext{
${ }^{22}$ A brief summary of this structure could be given as follows: Pure experience is defined as being equivalent to direct experience before any distinctions have been made (i.e., between subject and object or mind and matter). This claim refers not only to a psychological state of being unaware of such differences, but rather to the ontological fact that there must be an underlying unity in experience. Yet, as change inevitably occurs within experience, rifts open up within this underlying unity. This creates a constant process in which pure experience is simultaneously being made to distinguish itself into oppositions (such as subject and object) and reclaim its original unified state. Whether it be in the form of the volitional subject uniting with the object they desire through action or the epistemic subject unifying disjointed experience about an object they know nothing about through judgment, the very structure of experience is thus that it oscillates between rupture (as a result of change) and reunification. However, it is this very process that generates context in pure experience and - thus - makes it possible to identify subject/object, mind/matter, or self/other as perspectives within pure experience.

${ }^{23}$ This is indicated by the oft-cited reminder from Nishida himself at the beginning of An Inquiry into the Good's new edition in which he states " $[\mathrm{t}]$ hat which I called in the present book the world of direct or pure experience I have now come to think of as the world of historical reality. The world of action-intuition - the world of poiesis - is none other than the world of pure experience." (Nishida 1990, xxxiii).
} 
matter. Yet, as we have seen in the previous section, recognizing the fact that reality cannot be reduced to one or the other does not constitute a systematic philosophical understanding of it. Paradoxically, then, while pure experience was that which is given to us in our most obvious and direct experiences, it is also that which we need to clarify and structuralize (using Nishida's own words, it is the 'alpha and omega' of thought). ${ }^{24}$ Put differently, for Nishida, pure experience was both the point of departure and the final goal of philosophical contemplation. While this may seem like a banal fact, this difference in starting point is evidence of a crucial methodological difference between Nishida and Inoue insofar as it allowed for the possibility of claiming that positive descriptions of pure experience were possible without abstracting what was concretely given. Here, we will briefly review Nishida's notion of pure experience as a critical methodology and, in the process, show how it contributed to facing the problems setforth in the previous section.

So, what does it mean to talk about the philosophical methodology of pure experience? Borrowing from Nishida, we can see a succinct explanation of how the philosophy of pure experience can be understood in the following quotation:

"To understand true reality and to know the true nature of the universe and human life, we must discard all artificial assumptions, doubt whatever can be doubted, and proceed on the basis of direct and indubitable knowledge." (Nishida 1990, 38)

In regard to what he means by direct knowledge, Nishida then specifies as follows.

"It is knowledge of facts in our intuitive experience, knowledge of phenomena of consciousness. A present phenomenon of consciousness and our being conscious of it are identical; they cannot be divided into subject and object. Since facts are not separated even a hair's breadth from knowing, we cannot doubt this knowledge." (Nishida 1990, 39)

The idea is, at a glance, simple enough. To do philosophy is to doubt all that can be doubted, discard all our assumptions, and return to pre-reflective, lived experience. Through this practice, we can come to grips with concrete reality as it is before subject and object have been split apart and allowed themselves to be manipulated by inferences, linguistic infidelities, and fabrications of reflection. Yet, in spite of the superficial simplicity of this quasiCartesian outlook, a more careful look reveals that this change in starting point entails two crucial differences in how we approach philosophical argumentation.

The main difference we must account for in Nishida's methodology is obvious enough (and indeed, previous studies like Itabashi Yüjin's exploration of Nishida's relation to Inoue Tetsujirō have highlighted its importance in separating Nishida from his predecessors). ${ }^{25}$ In addition to establishing pure experience as what is given to us - our new starting

\footnotetext{
${ }^{24}$ Nishida 1990, 16

${ }^{25}$ Itabashi (2004) highlights in particular the struggles that Inoue Tetsujirō had in grounding any objective claim to philosophical knowledge in comparison with Nishida and his use of pure experience as a standard for truth.
} 
point, as it were - we also gain a methodological foundation of sorts with which to both make observations about pure experience as well as corroborate said observations. In this sense, although Nishida's view of pure experience may indeed be discussed in similar terms as Inoue's middle path, the metaphorical explanations provided by Enryō-sensei are certainly nowhere to be found in Nishida's early philosophy. In their place, Nishida provides a structural account of the workings of thought and the will and how they allow for experiences to develop the meaning or context necessary to distinguish varying perspectives. Thus, while Inoue's support for his notion of the middle path was based on the mutual negation of relative positions (and thus lacked positive corroboration), Nishida's arguments in his early philosophy aimed to illuminate the structures of reality based on what could be corroborated by direct or pure experience. The goal of pure experience as a methodology, then, was to start from direct experience and provide a faithful account of it without devolving into the kind of abstract or external standpoints that Inoue had already deftly shown to be insufficient.

Of course, one may doubt whether (1) Nishida's conception of pure experience itself is not a mere fabrication of reflection or (2) whether such a direct attempt to put pure experience into words presents his non-dual ontology in a merely abstract way. Put more generally, one could ask how it is possible to make any kind of faithful judgment about pure experience when (by definition) it stands prior to the distinction between a reflecting subject and her object of reflection. In response to these problems, it is important to recognize how Nishida attempted to develop a theory of meaning that is "internal" to pure experience. Although at times (in many respects similar to Inoue's skeptical outlook) Nishida states during An Inquiry into the Good that pure experience itself is not immediately or fully graspable by language, ${ }^{26}$ this is only true insofar as individual conscious experiences are mute without their proper context. Thus, crucial to Nishida's attempted solution is his explanation of how experiences can be bestowed with meaning by their relations with other experiences.

\begin{abstract}
"Assuming that pure experience is endowed with discriminations, what are the meanings or judgments added to it and how do they relate to pure experience? People usually argue that when pure experience is connected to objective reality it generates meaning and takes the form of judgments, but from the perspective of my theory of pure experience, we cannot leave the sphere of pure experience. Meanings or judgments derive from the connection of a present consciousness to a past consciousness; meanings and judgments are based on the unifying activity in the great network of consciousness. [...] For example, when one interprets an auditory sensation to be the sound of a bell, one has merely established the sensation's position relative to past experiences." (Nishida 1990, 9)
\end{abstract}

To paraphrase, meaning is generated in pure experience by allowing one experience to connect with other experiences (in this case, one's present experience of hearing a bell

\footnotetext{
${ }^{26}$ Consider, for instance, Nishida's statement that "True reality, like the true meaning of art, is not something that can be transmitted from one person to another. All we can transmit is an abstract shell. We may think that by means of the same language we understand the same thing, but to some extent the content necessarily differs." (Nishida 1990, 51-2)
} 
is made possible by having heard bells before in the past). Here, the implicit relations between such experiences are made explicit in judgment. ${ }^{27}$ In this case, the initial confusion that comes with wondering "what was that noise" is answered by referencing our previous experiences, resulting in the judgment that "it was just a bell."

Hence, we can see that meaning is not bestowed upon pure experience by the mental act of an epistemic subject that stands outside of it, but rather from the implicit connections between one conscious experience and another making themselves explicit. Yet, how could one possibly determine whether or not these judgments were true or not without presupposing an external entity with which this internal position is correlative to? Along similar lines, Nishida solves this by claiming that whether judgments were true or false was also determined by the systematic relation between experiences:

"Which ideas are true and which false? We always believe that what is most powerful, greatest, and deepest in a system of consciousness is objective reality. Whatever fits with it we consider true, and whatever conflicts with it we consider false." (Nishida 1990, 15)

In this way, judgments, meanings, and truth could only be corroborated by their conformation with the systematic progression of what was given in the stream of consciousness. By extending these principles, we can extrapolate that the philosopher's job in their quest to describe pure experience as the sole reality, was to make explicit the structures of this "network of consciousnesses" from an internal position, without abstracting only one aspect of it or relying on empirically unverifiable suppositions of a mind-independent world or pre-individuated conscious subject.

It was this methodological principle that allowed Nishida to provide an internally consistent and thoroughgoing account of both the standard for admitting evidence in a philosophy of pure experience as well as how judgments needed to establish that standard could be made in the first place. In this way, Nishida attempted to give a positive description of a non-dual account of reality without ever abstracting only one aspect of experience from another (as would be the case in extreme positions such as idealism and materialism). By following this plan of attack, Nishida presented an alternative to Inoue's view and - in doing so - offered a path for further philosophical reflection on a non-dual ontological framework that, by nature, defies external characterization. Naturally, this does not mean that Nishida's early methodology was entirely sound. Indeed, the notion that Nishida's early philosophy fell prey to psychologism is one widely accepted testament to this point. ${ }^{28}$ Yet, whether or not he succeeded is not

\footnotetext{
${ }^{27}$ Naturally, the word implicit may appear out of place or not sufficiently justified here. However, a brief reminder that the early Nishida's understood universals as "seeds" implicit in experience that are drawn out as concretely in the individual as consciousness develops itself. The upshot of this is that Nishida's essences and universals can connect "by themselves" to a certain degree. For example, several experiences of individual red objects draw out the underlying pattern we refer to as red. Yet, crucially, this does not imply a pre-given notion of redness that stands prior to experience, for doing so presupposes that these red objects have been put in touch with each other in what Nishida refers to as the "network of consciousness."

${ }^{28}$ A useful reconstruction of precisely how and why Nishida succumbed to psychologism (as well as the problems this presents to his philosophy) is available in Mitsuhara (2018).
} 
the point. In spite of his own potential shortcomings, we find in Nishida's early philosophy a key change in directions from Inoue that contributed greatly to later trends in twentieth century Japanese philosophy: a path to logicizing a conception of reality that cannot be reduced to one position and can accommodate the dynamic interplay between the various conflicting, relative positions that all constitute one aspect our lived experience.

\section{Conclusion - Nishida Kitarō and the "Beginning" of Philosophy in Japan}

Over the course of this paper, we have aimed to introduce the philosophy of Inoue Enryō as setting the stage for the philosophy of Nishida Kitarō as well as investigate what is different between them. As we have seen, although it may perhaps sound trivial at first glance, the difference in starting points between Inoue and Nishida proved to be an important step in providing a more systematic account of a similar conception of reality that cannot be reduced to abstract positions such as idealism or materialism. Indeed, while Inoue's dialectic stops once it reaches a non-dual conception of reality referred to as the middle path, Nishida instead attempts to provide a positive analysis of the structures of his worldview. Naturally, this difference between the two does not indicate a flaw or failure on Inoue's part. However, it is still noteworthy that Nishida's use of pure experience as a methodological principle to provide a comprehensive and systematic account for these ideas did help him achieve a level of positive description that was not available in Inoue's thought. The question that remains, then, is what these observations can tell us about our initial concern with the common narrative that Nishida was the first "original" philosopher in modern Japan.

On the one hand, Nishida's comprehensive effort to systematically detail the structures of pure experience shows a crucial difference between him and Inoue (and, likely, any of his other predecessors) concerning how philosophy was to be approached. In other words, Nishida's more positive explanations and use of pure experience as a foundation for his philosophical claims mark an important difference in what was expected from philosophical argumentation. In this sense, it seems hard to entirely deny that there is some truth to this widely accepted narrative and its role in helping shape the way we understand, categorize, and discuss the history of philosophy in Japan. On the other hand, however, the results of our investigation simultaneously emphasize the precarious position we find ourselves in when we accept the narrative that Nishida is the definitive beginning of modern Japanese philosophy. That is to say, not only can well-informed comparative analyses show a great deal of continuity between Nishida and philosophers in the European and American traditions (as many scholars have adeptly shown over the years), but it can potentially point us toward a greater deal of continuity in the Japanese philosophical tradition than is typically recognized. As we have seen in this example, to dismiss the theoretical value of Inoue's dialectic and the influence it had on Nishida by ignoring its connection to Nishida's philosophy would be a mistake. Considering these conflicting conclusions, we would be justified in saying that neither an uncritical affirmation nor denial of Nishida's reputation as Japan's first modern philosopher would be helpful. 
Yet, this conclusion should not be looked at as a mere contradiction. To the contrary, it can provide important practical lessons for further studies of both Nishida's philosophy and the history of philosophy in Japan. Specifically, such studies can help us reconsider how we should approach the currently accepted "cut" between Nishida and his contemporary Meiji philosophers can be helpful in establishing distinctions between eras as needed to organize history books, class syllabi, and other resources. Indeed, as have seen in this analysis of Nishida's relation to Inoue, relativizing the commonplace narratives that we have relied upon cannot only help us avoid the trap of looking at modern Japanese philosophy as though it started instantaneously with Nishida's philosophy, it can also give us a deeper perspective on Nishida's own work.

Acknowledgements I would like to offer my thanks to the anonymous peer-reviewers for their helpful suggestions, as well as to Taguchi Shigeru (Hokkaido University) and Andrea Altobrando (University of Padua) for their comments on this paper.

\section{References}

\section{Abbreviations and Complete Works}

IES (1987) 『井上円了選集』[Selected Works of Inoue Enryō]. Tokyo, Toyo University Press.

Davis, Bret W. (2019). “The Kyoto School”, The Stanford Encyclopedia of Philosophy. Edward N. Zalta (ed.). URL $=<$ https://plato.stanford.edu/archives/sum2019/entries/kyoto-school/ $>$. Accessed December $29,2019$.

Funayama, Shinichi 船山信一. 1959/1965. 『明治哲学史研究』 [Research on Meiji Philosophy]. Kyoto: Minerva Shobo.

Godart, Gerard Clinton. (2004). Tracing the Circle of Truth: Inoue Enryō on the History of Philosophy and Buddhism. The Eastern Buddhist, Vol. XXXVI (December), 106-133.

Itabashi, Y. 板橋勇仁. (2004). 『西田哲学の論理と方法一徹底的批評主義とは何か』[Logic and Method of Nishida Philosophy: NIshida, Fichte, and Neokantians]. Tokyo: Hosei Daigaku Shuppankyoku.

Josephson, J. A.. (2006). When Buddhism Became a "Religion": Religion and Superstition in the Writings of Inoue Enryō. Japanese Journal of Religious Studies, 33(1), 143-168.

Kopf, G.. (2013). The "Modern Buddhism” of Inoue Enryō. Kokusai Inoue Enryō Kenkyū, vol. 1. 25-36.

Kosaka, K. 小阪国継. (1995). 『西田幾多郎一その思想と現代一』 [Nishida Kitarō - His Thought and the Present]. Kyoto: Minerva Shobo.

Kosaka, M. 小坂正明. (1959/1999).『明治思想史』[Meiji Intellectual History]. Ed. Minamoto Ryoen. Tokyo: Toeisha.

Kosaka, M. 小坂正明. 1971.『西田幾多郎先生の生涯と思想』[The Life and Thought of Professor Nishida]. Tokyo: Kokusai Nihon Kenkyūjo.

Maraldo, J. C. (2017). Japanese Philosophy in the Making 1: Crossing Paths with Nishida. Nagoya: Chisokudo Publications.

Mitsuhara, T. 満原健. (2018). 「『善の研究』と理主義」[An Inquiry into the Good and Psychologism] Nishida Tetsugakkai Nenpō, 15, 159-173.

Nishida, K. (1990). An Inquiry into the Good. Masao Abe and Christopher Ives trans., New Haven and London: Yale University Press.

Nishida, H. (2003). 『西田幾多郎全集』[The Complete Works of Nishida Kitarō volume 24]. Tokyo, Iwanami Shoten.

Nitta, Y.. 新田義弘 (1989). 「井上円了の現象即実在論」 [Inoue Enryō's Theory of Phenomena-qua-Reality] in Saitō, Shigeo ed., 『井上円了と西洋思想』[Inoue Enryō and Western Thought] (pp: 79-102). Tokyo: Toyo Daigaku Inoue Enryō Kenkyū Dainibukai.

Okada, M. (2005). Revitalization versus Unification: A Comparison of the Ideas of Inoue Enryō and Murakami Senshō The Eastern Buddhist, vol. 1 (no. 37), 28-38. 
Paramore, K. (2009). Ideology and Christianity in Japan. London: Routledge.

Pyle, K. B. (1969). The new generation in Meiji Japan: problems of cultural identity, 1885-1895. Palo Alto: Stanford University Press.

Schultzer, R. (2019). Inoue Enryō: A Philosophical Portrait. New York: SUNY Press.

Shimomura, Toratarō 下村寅太郎. 1990. 西田哲学と日本の思想 [Nishida Kitarō and Japanese Thought]. Tokyo: Misuzu Shobo.

Shirai, Masato 白井雅人. 2012. 「井上円了『哲学一夕話』と田幾多郎」 [Inoue Enryō's An Evening of Philosophical Conversation and Nishida Kitarō]. Journal of International Philosophy, vol. 1, 101-108.

Snodgrass, J. (2003). Presenting Japanese Buddhism to the West: Orientalism, Occidentalism, and the Columbian Exposition. Chapel Hill: The University of North Carolina Press.

Staggs, K. (1983). Defend the Nation and Love the Truth: Inoue Enryō and the Revival of Meiji Buddhism. Monumenta Nipponica, 38(3), 251-281.

Takeuchi, Yoshitomo. 竹内良知. (1970). 『西田幾多郎』[Nishida Kitarō]. Tokyo: Tokyo Daigaku Shuppankai. Wargo, R. J. J. (2005). The Logic of Nothingness. Honolulu: University of Hawaii Press.

Watabe, K. 渡部清 (1998). 「仏教哲学者としての原坦山と「現象即実在論」との関係」[Hara Tanzan as a Buddhist Philosopher and his Relation to theories of Phenomena-qua-Reality] in Philosophical Studies, vol. 24, 89-113. 